\title{
JEAN-BAPTISTE TIERCE AND THE BATAVIAN REPUBLIC
}

The revolution of 1795 in the Republic of the Seven United Provinces and the European war affected the events and status of the Dutch colonies. The island of Curaçao, the most important of the Netherlands Antilles, was no exception and experienced a series of internal changes and finally even a change in colonial masters when it was conquered by Great Britain in 1800 and again in 1807. One of the most dramatic internal episodes occurred in September 1799 when the colonial government of Curaçao expelled a French citizen, Jean-Baptiste Tierce, for his alleged participation in a conspiracy and plot against the authorities. After his expulsion, Tierce's ordeal was not over since he was incarcerated in the Batavian Republic where he had hoped to obtain justice. While the events of Tierce's arrest and expulsion are well known, his imprisonment in the Netherlands and its diplomatic repercussions have not been given any attention. This article will attempt to present an account of Tierce's experiences in the Batavian Republic in 1800 and 1801.

Curaçao had been a Dutch colony since 1634 and like other European colonies in the West Indies relied heavily on the institution of slavery to sustain its economy. In 1789 the number of slaves was 12,804 as opposed to 3964 whites and 2776 free colored. On the island also lived a large number of other Europeans besides the Dutch such as some 400 French citizens. Partly as a result of the impact of the French Revolution and the slave revolt in French Santo Domingo an insurrection among the slaves occurred in August 1795. It failed, however, and the leaders were executed.

News of the flight of Stadholder William V reached Curaçao on May 16, 1795, but the old colonial government remained in office much to the chagrin of the Patriotic elements. On August 10,1796 , it became known that the stadholderate had been abolished, and, therefore, no one would henceforth be bound by the oath of loyalty. The officials swore their allegiance to the Batavian regime, and a new director ad interim, Jan Jacob Beaujon, was appointed while Johann R. Lauffer became the commander of the national guard. Soon Beaujon and Lauffer disagreed over such matters as defense, and the former was forced to resign in December 1796 to be replaced by his rival. 1 
Lauffer was born in Switzerland and had come to Curaçao as a soldier in 1776 . He earned the respect of many of the local inhabitants and sided with the advocates of change although he was not a radical. His task was not simple since he not only had to watch the enemy, the British, but also his allies, the French, who were perhaps more of a threat to the island. The French Republic had dispatched many agents to the Caribbean some of whom were most anxious to establish a French regime in Curaçao. With the growing chaos in Santo Domingo the number of French refugees increased, and Lauffer realized that they might pose a potential threat to his administration.

Among the well established French citizens in Curaçao was JeanBaptiste Tierce. He was born in Le Hâvre in 1754 and came to the island in 1784.2 In the course of time Tierce accumulated 'a small fortune and credit.' 3 He was widely respected in the business world 4 and by others and played an important role in his local Catholic Church where he served as eerste kerkmeester. $5 \mathrm{He}$ also assisted in the suppression of the slave revolt in $1795^{6}$ and he supported the Patriots. He and others demanded in September and December 1796 to place Captain First Class, Albert Kikkert, and Lauffer in charge of the defense of the island since Beaujon seemed not aggressive enough to prepare the island for a possible outside attack. $7 \mathrm{He}$ also attacked Rear-Admiral Wiertsz even accussing him of treasonable conduct since the latter had allegedly once agreed to surrender Willemstad to the British. Wiertsz was furious over the accusation and complained to the colonial council 'how slanderous, how dishonorable, how grievious' a certain Tierce had dared to accuse him. 8

On July 3, 1796, Tierce was appointed to fulfill the French consular function relative to the sale of prizes on the island of Curaçao. On September 10, 1798, he was appointed receveur of French prizes which entitled him to keep $5 \%$ of the receipts. His consular activities were terminated in April 1798, and in June 1799 Tierce was replaced as receveur by General Urbain Devaux.9 A few months later Tierce was imprisoned and deported for participation in a plot against the colonial government.

Why Tierce became the principal ringleader of this cabal against Lauffer's administration is not clear. He had once been an active supporter of the director and even supported his appointment. Lauffer alleged once that Tierce had since 1796 thwarted the 
government in every possible way and spread 'the most infamous lies' about the Curaçao government among the neighboring French possessions. 10 There is no evidence to support that accusation, however. It is possible that Tierce was politically naive and was persuaded by frustrated and disgruntled French refugees to overthrow Lauffer's government and to install Kikkert who was more pro-French. The available evidence seems to indicate that Kikkert, who was no friend of Lauffer, played a somewhat sinister role in this affair. He undoubtedly had secret ambitions to become director of the island, a position he finally obtained in 1815 . Furthermore, he and Tierce were and remained close friends even after the disaster of September 1799. 11

It is not clear when the first rumors of a plot against his administration reached Lauffer. Later he contended that his enemies would have tried to stage a coup d'état as early as 1797, but fear of Rear Admiral Wiertsz caused them to hesitate. After the latter's death in October 1798 the cabal became bolder and searched for a suitable leader. 12 In August 1799 Lauffer informed the Committee for the Affairs of the Colonies and Possessions of the Batavian Republic in America and the Coast of Guinea that the National Guard had enabled him 'to foil completely all the attempts by the still active cabal.' 13 However, on September 8 he reported to his Colonial Council in Curaçao that he had received significant information about a plot led by General Devaux against his government. Apparently, the original plot had called for an expedition to be launched from Santo Domingo, an undertaking for which the leader of the slave revolt in that French colony, Toussaint l'Ouverture, would furnish ships and men. However, the plan was changed, and it was decided to stage a coup d'état against Lauffer who would be replaced by Kikkert. One of the first acts of the new government would be the freeing of the slaves. If the plot had succeeded, Lauffer wrote, 'this most terrible undertaking' would have resulted in 'a most horrible massacre' and Curaçao and the entire West Indies might have shared the fate of Santo Domingo. 14

The Colonial Council of Curaçao was impressed with Lauffer's evidence and ordered the immediate arrest and deportation of General Devaux. The latter vigorously denied any complicity in the plot, 15 and most likely he was only marginally involved. Lauffer himself wrote later that Devaux was not a man with an 'evil heart' but had a rather 'fiery imagination' and was 'immature' in his opinions. 16 
A few days later Lauffer concluded, however, that not Devaux but Tierce had been the principal ringleader, and on September 13 he requested the Colonial Council to order his arrest, a request that was promptly granted. Furthermore, it was later revealed that Tierce had been in secret communication with Spanish rebels from Caracas and had even helped one of them, a certain Pedro Cannibens, to escape. 17 The Colonial Council searched Tierce's house on September 18 but could find no incriminating evidence except for some papers that tended to prove that he had been active for some time in stirring up the French authorities against the government of Curacao.18 Tierce's priest, Jacobus Schinck, tried desperately to testify on Tierce's behalf, but the Colonial Council could not be persuaded, and on September 26 ordered his expulsion from the island within eight days. 19 Tierce left the island on October 7. He had barely time to arrange his private affairs and begged a friend to care for and have mercy on his children and their mother. 20

Tierce went first to Spanish Santo Domingo and then to Cap Français where he boarded a French ship bound for Bordeaux. However, this vessel was seized by an American frigate and brought first to Newport and later to Boston. Here he boarded the Mahale Winsor bound for Rotterdam where he arrived on May 11 or 12,1800 . In the Batavian Republic he hoped to be given a chance to vindicate himself. Subsequently, he intended to go to Paris to discuss his problems with the minister of navy and colonies. 21

With Tierce from Curaçao to Boston and to Rotterdam travelled another inhabitant of Curaçao, Jan Hendrik Quast, Quast was a young naval officer and the son of Johan Caspar Adolf Quast, the late pastor of the Protestant congregation in Curaçao. He had not been involved in the cabal against Lauffer although he and Tierce seemed to have been close friends. Quast claimed he was simply travelling to Europe to settle some of his business affairs after which he intended to return to Curaçao where his wife and children still lived. 22

Upon his arrival in the Batavian Republic Tierce soon learned, especially from Hubertus Coerman, a member of the Committee for the Affairs of the Colonies, that the authorities had been fully informed about the events of September 1799. Thus he soon realized he could not expect to receive a sympathetic or unbiased hearing, and resolved to go to Paris. 23 
However, on May 19, the Agent of General Internal Police, A.J. La Pierre, decided to arrest Tierce and Quast. During the interrogation in the days following Tierce vigorously denied any complicity in a plot to overthrow the government of Curaçao. He did acknowledge that he had had contact with Spanish rebels from Caracas and at the request of Director Lauffer hid one in his house. He was exiled, he charged, because Lauffer disliked him since Tierce was a 'good friend' of Kikkert. Furthermore, he added that the patriots in Curaçao were dissatisfied with Lauffer because he was despotic. Quast also denied any complicity although it appeared that the French agent in Spanish Santo Domingo had paid his travel expenses from Cap Français to France. 24

Although the interrogation had not provided La Pierre with anything very incriminating, the Agent resolved on June 6 to request the Uitvoerend Bewind for permission to hand over Tierce and Quast to the judical officials. The Directors readily agreed on June 7 provided that the Legislative Body recognize the Court of Holland and Zeeland's competence to prosecute the two men who were allegedly guilty of crimes committed in the colonies. At this time the Batavian government had not yet settled the question if a person who had committed a crime in the colonies could be tried by a court in the Republic. This problem was easily solved, however, when the Legislative Body on June 26, 1800, passed a decree empowering the Court to prosecute Tierce and Quast. 25

By this time the case against Tierce and Quast had produced a serious crisis in the Committee for the Affairs of the Colonies. On June 6, while recommending Tierce and Quast's prosecution by the Court, La Pierre also charged one of the members of the Committee tor the Affairs of the Colonies, Hubertus Coerman, with improper conduct that warranted his temporary exclusion from that body. 26 Coerman once resided in Curaçao where he served as advocaat fiscaal and as a member of the grootenraad. 27 Although he was living in the Batavian Republic in 1800, his wife had remained in Curaçao. He knew Tierce and also Quast and these two men had immediately contacted him upon their arrival in Rotterdam in May. Undoubtedly, Coerman sympathized with the two men and divulged information to them, especially on Lauffer's communication with the Committee for the Affairs of the Colonies that he, as a member of that body, should have kept confidential. La Pierre learned about Coerman's indiscretion 
during the interrogation and demanded the latter's exclusion from the Committee.

The Uitvoerend Bewind was not willing to accept La Pierre's recommendation but did demand on June 11 that every member of the Committe for the Affairs of the Colonies submit a written statement declaring that they had not had any communication with Tierce. 28

All the members of the Committee for the Affairs of the Colonies, except Coerman, promptly complied with this request. 29 Coerman promised to submit a separate statement which he did on June 15. In it he acknowledged that he had known Tierce when he lived in Curaçao and had been pleased to meet him again. He respected Tierce for his role in the suppression of the slave revolt and considered the exile of his friend from the island an act of injustice. Coerman contended that Tierce most likely had been deported because he had discovered serious dishonesty in the execution of the will of a certain Brion. Coerman did deny, however, that he had divulged anything of substance to Tierce although he did acknowledge having had conversations with him. 30

Upon the request of the Uitvoerend Bewind, the Committee for the Affairs of the Colonies reluctantly expressed its views on Coerman's behavior. It agreed that he had been guilty of indiscretion and added that it had never been too impressed with Coerman's role on the Committee because of his 'turbulence and temperamental constitution'.31 Subsequently, the Uitvoerend Bewind on July 26 expressed its 'serious displeasure' over Coerman's 'thoughtless temper and imprudence' and urged him to be more careful in the future. 32

More serious were the diplomatic repercussions of the Tierce affair. Already a few days after Tierce's arrest the Spanish ambassador to the Batavian Republic, Anduago, requested the government not to release the prisoner before he had had an opportunity to interrogate him on the attempted coup d'état in Caracas. 33 While this request, which was repeated in late July, could be honored, the demands submitted by the French ambassador Sémonville produced a more serious problem. Already on May 27 Sémonville demanded that if Tierce were a French citizen employed as French consul in Curaçao he be promptly released. 34 Two weeks later the French ambassador demanded that all decisions against Tierce, who was undoubtedly a French citizen and 
therefore entitled to the protection of his government, be suspended. Furthermore, Sémonville demanded that his secretary be permitted to question the prisoner. 35 The Uitvoerend Bewind requested La Pierre on June 12 to advise the foreign minister how to reply to Sémonville's inquiries and demands. La Pierre denied that Tierce was a French citizen since he had become a Batavian citizen because of his service as an officer in the national guard. Furthermore, although Tierce had once served as French consul, he was never officially appointed to that function by the French government. Moreover, his consular duties ended in April 1798 almost one and one-half year before his arrest and expulsion. Later Tierce served as receveur, but he held that position only at the fiat of the Batavian officials. Therefore, La Pierre concluded, Tierce could not under any circumstances appeal for protection of the French government. Naturally, the request to allow Sémonville's secretary question Tierce could not be honored since such a concession would violate Dutch sovereignty and do harm to Batavian-French relations. 36

The Uitvoerend Bewind accepted La Pierre's advice and on June 16 instructed Foreign Minister Van der Goes to reply to Sémonville accordingly. 37 The latter was unwilling to accept this rebuff and reiterated with 'greater force' his previous observations and demanded Tierce's prompt release. He accused the Batavian authorities of subterfuges in order to suspend his intervention to obtain the release of a person who had been victimized by the enemies of the Batavian government in Curaçao where Tierce had successfully foiled the intrigues of the Orangists. 38

The Batavian government, which was often easily bullied by the French during this time, stubbornly refused to yield in this matter, however. It even instructed on August 6, 1800, the ambassador to Paris, Rutger Jan Schimmelpenninck, to submit a memorandum to the French government on the events in September 1799 in Curaçao and to inform the authorities of 'the unhealthiness of the claim to consider J.B. Tierce . . . a French citizen.' 39

In September 1800 the French government discontinued its demands on behalf of Tierce. Perhaps it felt it could no longer defend Tierce who had been accused of trying to overthrow the government of Curaçao in 1799 after un unofficial, abortive, French attack on the island between July and September 1800 . This time the Batavian government registered protests and the French authorities attempted to apologize. 40 
Meanwhile, Tierce and Quast had been in the custody of the Court of Holland and Zeeland which studied the available evidence to enable them to instigate legal actions against the two men. However, on July 24 the Court resolved that since it could not find sufficient evidence to prosecute them, the two men would be released on July 28, 1800.41 The Spanish ambassador attempted desperately to detain them further while he was awaiting for relevant documentary material from Madrid, which would enable him to interrogate Tierce on the Caracas affair. The Uitvoerend Bewind honored that request on July 28,42 but the Court refused to relent much. It emphasized the difficulties of this case that could not be handled 'in accordance with regular rules.' However, it could not detain the two men merely on the basis of 'vague accusations.' There simply was not enough evidence and no corpus delicti. However, the Court was willing to keep Tierce until August 1 'in order not to render illusive such political measures as [the Directors] in their position might deem necessary.' 43

The Court's record on human rights during the period 1798-1804 has not been very impressive. It was especially sensitive to what it considered abuses of freedom of the press, and in May 1802 gave a rather severe sentence to J.C. Hespe for publishing two innocent 'dreams' in the Politieke Blixem. However, the case against Tierce and Quast was handled with equity, although the Court played a little game with its reference to 'political measures.' What was meant by that became obvious when the Uitvoerend Bewind resolved on July 30 to order La Pierre to reincarcerate Tierce upon his release by the Court for the security of the state and for the maintenance of good relations with the Republic's allies. Thus the Court informed La Pierre of the time and place of Tierce's release on August 1, and on that day the latter found himself again in the custody of the Agent of Internal Police. 44

Tierce remained incarcerated until late October 1800 when he 'escaped.' Most likely, Tierce was allowed to escape in order to rid the Batavian government of what was becoming an embarrassing problem. Already in late September Delprat noted in his diary that the government had resolved to allow Tierce to escape. 45 Apparently, it took some effort to let the prisoner out of the cage. On October $15 \mathrm{La}$ Pierre authorized one of his clerks to move Tierce from the Gevangenpoort to the Mauritshuis because of the dampness of his cell. This transfer was effected without difficulty that same day. However, on October 23 Tierce's brother Emma- 
nuel, who had been permitted to visit him for several weeks, requested that his brother be returned to the Gevangenpoort because his cell was too cold for a person who had lived for more than 30 years in the tropics. Again La Pierre consented, but during this transfer the next day Tierce with the assistance of others broke loose from his guards and disappeared in the darkness of the evening. 46

Tierce safely arrived in Paris, but he refused to concede defeat. In December 1800 he forwarded an eight-page pamphlet 47 to the Batavian government in which he tried to defend and vindicate himself. He lamented his suffering at the hands of the Orangists in Curaçao and accused Lauffer of being "crafty and dissimulating.' He had neglected the defense of the island, Tierce charged, and refused to listen to him and Kikkert to prepare Curaçao for a possible outside attack. In conclusion, Tierce requested permission to return to Curaçao to attend to his business, his extensive and complicated administration, and to repair all the damage Lauffer had caused to his house, warehouse and commerce. Naturally, the Batavian government refused to relent and Tierce received no reply.

This was not the end of the Tierce affair, however. On March 18, 1801 , reports reached La Pierre that Tierce had had the audacity to return to the Batavian Republic. Immediately, the Agent asked the Uitvoerend Bewind for permission to arrest and deport him, a request that was promptly granted. 48 Tierce was arrested in Amsterdam on March 21 and deported two days later. Why had he returned to the Batavian Republic? 49 Most likely out of sheer frustration and desperation to obtain a favorable decision from the Batavian authorities to permit him to return to Curaçao. He might have hoped that his friend Kikkert, who had returned home, to assist him. But Kikkert had no influence with the authorities, and to the best of my knowledge, Tierce never returned to his beloved Curaçao. 


\section{NOTES}

1. J. Hartog, Curaçao van Kolonie tot Autonomie (Aruba, 1961), I, p. $324 \mathrm{ff}$., $467 f f ., 568-569$. - J.H.J. Hamelberg, 'Een veelbewogen Tijdperk. Een achttal Jaren uit de Geschiedenis van Curaçao, 1796-1804,' Eerste Jaarlijks Verslag van het Geschied-, Taal-, Land-, en Volkenkundig Genootschap (Amsterdam, 1897), p. 24-44.

2. The Hague, Algemeen Rijksarchief. Binnenlandsche Zaken, 1795-1813. Agent van Algemene Inwendige Politie en Binnenlandsche Correspondentie en Toezicht op de Staat der Dijken, Wegen en Wateren der Bataafsche Republiek. Secret Minutes, no. 222. - Hereafter, Algemeen Rijksarchief will be cited as A.R.

3. (Jean Baptiste Tierce), Au gouvernement batave (n.p., [1800]), 8 pp.

4. A colleague of Tierce, B. Tobel, even referred to Tierce as the 'steunpilaar van onze beurs'. The Hague, Algemeen Rijksarchief. Hof van Holland, Criminal Papers, no. 5608. - Hereafter, this source will be cited as A.R., H.H.

5. Ibid. His priest, Jacobus Schinck, praised Tierce for his 'loyal service'. Ibid.

6. Ibid.

7. The Hague, Algemeen Rijksarchief. Comité tot de Zaken van de Koloniën en Bezittingen op de Kust van Guinea en in Amerika. Minutes of Police, Governors and Council of Curaçao, 1796-1799, no. 138. - Hereafter, this source will be cited as Comité van de Koloniën.

8. Ibid.

9. A.R., H.H., Criminal Papers, no. 5608; A.R., Agent Algemene Politie, Secret Minutes, no. 222 and Secret Related Documents, no. 228.

10. A.R., Comité van de Koloniën, Minutes of Police, Governors and Council of Curaçao, no. 138 .

11. See relevant documents in A.R., H.H., Criminal Papers, no. 5608. Kikkert survived the events of Sept. 1799, but he was recalled in June. A.R., Uitvoerend Bewind, Secret Related Documents, no. 473. On Kikkert see also J.M.G.A. Dronkers, De Admiraals van het Koninkrijk Holland, 1806-1810 (n.p., n.d.), p. 44-46.

12. Lauffer to Comité van de Koloniën, Nov. 7, 1799. A.R., Comité van de Koloniën, Messages and Enclosures from Curaçao, 1796-1802, no. 136. A copy of this same letter can also be found in A.R., Agent Algemene Politie, Secret Related Documents, no. 228.

13. A.R., Comité van de Koloniën, Messages and Enclosures from Curaçao, no. 136. 
14. A.R., Comité van de Koloniën, Secret Minutes, no. 37, Minutes of Police, Governors, and Council of Curaçao, no. 138, Messages and Enclosures from Curaşao, no. 136. See also A.R., H.H., Criminal Papers, no. 5608.

15. A.R., Comité van de Koloniën, Minutes of Police, Governors and Council of Curaçao, no. 138 .

16. Lauffer to Comité van de Koloniën, Sept. 13, 1799. A.R., Comité van de Koloniën, Messages and Enclosures from Curaçao, no. 136.

17. A.R., Comité van de Koloniën, Minutes of Police, Governors and Council of Curaçao, no. 138 and Messages and Enclosures from Curaçao, no. 136.

18. A.R., Comité van de Koloniën, Minutes of Police, Governors and Council of Curaçao, no. 138; A.R., Agent Algemene Politie, Secret Related Documents, no. 228

19. A.R., Comité van de Koloniën, Minutes of Police, Governors and Council of Curaçao, no. 138.

20. Ibid.

21. A.R., Agent Algemene Politie, Secret Minutes, no. 222 and Secret Related Documents, no. 228; A.R., H.H., Criminal Papers, no. 5608.

22. A.R., Agent Algemene Politie, Secret Minutes, no. 222 and Secret Related Documents, no. 228. On Quast's father see Nieuw Nederlandsch Biographisch Woordenboek (Leiden, 1927), VII, p. 1031-1032 and A.J.C. Krafft, Historie en oude Families van de Nederlandse Antillen (The Hague, 1951), p. 35, 57, 273.

23. A.R., H.H., Criminal Papers, no. 5608.

24. A.R., Agent Algemene Politie, Secret Minutes, no. 222 and Secret Related Documents, no. 228

25. Ibid.

26. A.R., Agent Algemene Politie, Secret Related Documents, no. 228.

27. The Hague, Centraal Bureau van Genealogie.

28. A.R., Uitvoerend Bewind, Secret Minutes, no. 461; A.R., Comité van de Koloniën, Secret Minutes, no. 38

29. A.R., Comité van de Koloniën. Secret Minutes, no. 38.

30. A.R., Uitvoerend Bewind, Secret Related Documents, no. 474.

31. Ibid. 
32. A.R., Uitvoerend Bewind, Secret Minutes, no. 461. Coerman's colleagues were not overstating their case when they referred to his 'turbulence and temperamental constitution.' On October 24, 1800 he attacked his landlord with a knife. A.R., H.H., Resolutions, no. 360.

33. A.R., Agent Algemene Politie, Secret Related Documents, no. 228.

34. A.R., Buitenlandsche Zaken, 1796-1810, Messages from the French government, no. 233 .

35. A.R., Agent Algemene Politie, Secret Related Documents, no. 228.

36. Ibid.

37. Ibid.

38. A.R., Buitenlandsche Zaken, 1796-1810, Messages from the French government, no. 233 .

39. A.R., Uitvoerend Bewind, Secret Minutes, no. 461; A.R., Buitenlandsche Zaken, 1796-1810, Ordinary and Secret Messages, no. 74 and Incoming Documents, no. 213.

40. A.R., Buitenlandsche Zaken, Incoming Documents, 213.

41. A.R., H.H., Resolutions, no. 360.

42. A.R., H.H., Criminal Papers, no. 5608.

43. A.R., Uitvoerend Bewind, Secret Related Documents, no. 474.

44. A.R., Agent van Algemene Politie, Secret Related Documents, no. 228; A.R., Uitvoerend Bewind, Secret Minutes, no. 461; A.R., H.H., Criminal Papers, no. 5608. Quast was not reimprisoned.

45. D.A. Delprat, 'Journal concernant les évènements politiques de notre patrie depuis 1798-1807', Bijdragen en Mededeelingen van het Historisch $\mathrm{Ge}$ nootschap, XIII (1892), p. 224.

46. A.R., Agent Algemene Politie, Secret Minutes, no. 222 and Related Secret Documents, no. 229.

47. Tierce, Au gouvernement batave, A.R., Agent Algemene Politie, Secret Related Documents, no. 229.

48. A.R., Agent Algemene Politie, Secret Minutes, no. 223 and Secret Related Documents, no. 230.

Gerlof D. Homan

Professor of History

Illinois State University

Bloomington-Normal 61761 